\title{
KINERJA ALAT PENGERING MEKANIS TIPE VERTIKAL UNTUK IKAN PETEK Leiognathus sp.
}

\author{
Performance of Vertical Type Mechanical Dryer for \\ Leiognathus sp. Fish
}

\author{
Jamal Basmal ${ }^{1 *}$, Bakti Berlyanto Sedayu ${ }^{2}$, dan Bagus Sediadi Bandol Utomo ${ }^{1}$ \\ ${ }^{1}$ Balai Besar Penelitian dan Pengembangan Pengolahan Produk dan Bioteknologi Kelautan dan Perikanan, KKP. \\ JI. K.S.Tubun Petamburan VI, Jakarta Pusat 10260 \\ ${ }^{2}$ Loka Penelitian dan Pengembangan Mekanisasi Pengolahan Hasil Perikanan, KKP. \\ JI. Imogiri Barat KM 11.5 Jetis, Bantul, DI Yogyakarta 55781 \\ * Korespondensi Penulis: jamalbasmal24@gmail.com
}

Diterima: 7 Januari 2013, Disetujui: 4 Juni 2013

\begin{abstract}
ABSTRAK
Percobaan pengeringan ikan petek Leiognathus sp. telah dilakukan menggunakan alat pengering mekanis tipe vertikal dengan dimensi $60 \mathrm{~cm} \times 60 \mathrm{~cm} \times 270 \mathrm{~cm}$ yang dilengkapi penarik udara dari dalam ruang pengering dengan daya 150 watt $(2.800 \mathrm{rpm})$. Dinding alat pengering terbuat dari lembaran akrilik dengan ketebalan $40 \mathrm{~mm}$. Alat pengering ini menggunakan bahan bakar LPG. Tujuan dari penelitian ini adalah untuk mengetahui kinerja alat pengering dan untuk mengetahui laju kecepatan penurunan bobot ikan. Ikan petek sebelum dikeringkan telah direndam dalam larutan garam 3\% selama 60 menit kemudian disusun di atas rak dengan kapasitas 1,74 $\mathrm{kg} / \mathrm{rak}$. Selanjutnya rak dimasukkan ke dalam ruang pengering. Percobaan ini dilakukan sebanyak 3 kali dan setiap ulangan menggunakan ikan petek sebanyak 10,44 kg. Lama pengeringan 720 menit yang menghabiskan LPG sebanyak $3,465 \mathrm{~kg}$ atau setara dengan 53,9 kkal/menit. Selama proses pengeringan diamati penurunan bobot ikan dan kadar air, serta kondisi lingkungan seperti suhu dan kelembaban yang diamati setiap 30 menit. Hasil percobaan menunjukkan bahwa suhu dan kelembaban di dalam ruang pengeringan berkisar antara $26,03-55,86^{\circ} \mathrm{C}$ dan $22,3-78,05 \%$. Jumlah bobot ikan yang hilang selama 720 menit proses pengeringan sebanyak $52 \%$. Kecenderungan penurunan bobot ikan diperoleh persamaan garis logaritma $y=-0,2 \ln (x)+$ 1.006 dengan nilai $r^{2}=0,999$. Kadar air diperoleh sebesar $47,94 \%$ dan nilai $a_{w} 0,483$.
\end{abstract}

KATAKUNCl: pengering mekanis, ikan petek, LPG, suhu, kelembaban

\section{ABSTRACT}

A prototype of vertical type mechanical dryer was used to dry Leiognathus $s p$. fish. The dimension of the dryer were $60 \mathrm{~cm} \times 60 \mathrm{~cm} \times 270 \mathrm{~cm}$. The dryer was equipped with 150 watt exhaust fan (2,800 rpm). The dryer wall was made from acryclic with $40 \mathrm{~mm}$ thickness. The dryer used liquid petroleum gas (LPG) fuel. The aim of the experiment was to identify the performance of vertical type mechanical dryer and the rate of fish weight lost. Before drying, fish was soaked in $3 \%$ of salt solution for 60 minutes and put on the tray with capacity of $1.74 \mathrm{~kg} / \mathrm{tray}$. The fish was put into drying cabinet. This test was done in three replications and each replication used $10.44 \mathrm{~kg}$. Total drying time 720 minutes and the amount of fuel used was $3.465 \mathrm{~kg}$ or equal with $53.9 \mathrm{kkal} /$ minute. Weight lost, moisture content and environmental condition (temperature and humidity) were measured during experiment. The measurement was done every 30 minutes. From the experiment, temperature and relative humidity of the dryer were ranged from $6.03-55.86^{\circ} \mathrm{C}$ and $22.30-78.05 \%$. Fish weight lost during drying was 52\%. The weight reduction was obtained from a linier regression, $y=-0.2 \ln (x)+1,006$; with $r^{2}=0.999$. The moisture content and $a_{w}$ of fish were $47.94 \%$ and 0.483 respectively.

KEYWORDS: mechanical dryer, Leiognathus sp., LPG, temperature, relative humidity

\section{PENDAHULUAN}

Pengeringan adalah salah satu upaya menguapkan sejumlah air dari bahan yang sedang dikeringkan dengan bantuan energi panas yang dilakukan melalui rambatan panas secara konveksi maupun konduksi di ruangan tertutup atau terbuka. Mulhbauer (1986) dan Bala (1997) mengatakan bahwa proses pengeringan merupakan cara yang paling sederhana, murah, efisien dan tidak mencemari 
lingkungan serta dapat kontak langsung ke permukaan ikan. Telah banyak penelitian dilakukan berkaitan dengan penggunaan energi panas matahari untuk mengeringkan produk pertanian secara konvensional (Exell \& Kornsakoo,1978; Exell \& Kornsakoo,1980; Zaman \& Bala, 1989; Esper \& Mulhbauer, 1993 \& 1994; Oosthuizen, 1995; dan Sharma et al., 1995; Oosthuizen, 1996; Ratti \& Majumdar, 1997; Bala \& Mondal, 2001; Bala et al., 2003; Karim \& Hawlader, 2005; Hossain \& Bala, 2007).

Adanya perbedaan panas antara permukaan dan bagian dalam bahan pangan mengakibatkan sejumlah uap air akan bergerak ke permukaan ikan akibat adanya perbedaan tekanan. Uap air yang jenuh di permukaan ikan akan menguap akibat adanya perbedaan tingkat kelembaban antara permukaan ikan dengan udara sekitar permukaan ikan. Laju penguapan di samping dipengaruhi oleh suhu juga dipengaruhi oleh tingkat kelembaban di sekitar ikan yang dikeringkan. Keberhasilan pengeringan ikan melalui pindah panas secara konveksi dari sinar matahari sangat tergantung pada adanya udara yang mengalir di permukaan ikan yang dikeringkan dan tingkat kelembaban udara. Untuk mengatasi hal tersebut, Hossain, 2003, Hossain et al., 2005a , dan Hossain et al., 2005 ${ }^{\mathrm{b}}$ telah melakukan uji coba pengeringan menggunakan solar tunnel dryer secara konveksi, namun pada musim hujan solar tunnel dryer kurang efektif karena tidak ada radiasi sinar matahari yang menembus solar tunnel dryer. Kelemahankelemahan yang ditemukan pada proses pengeringan menggunakan matahari dapat diatasi dengan mengganti energi panas matahari dengan bahan bakar dari limbah hasil pertanian yang merupakan bagian dari tanaman yang tersisa setelah dipanen atau diambil hasil utamanya seperti tempurung kelapa, serbuk gergaji, sekam padi, ampas tebu, jerami dan potongan kayu yang terdampar di pantai. Namun penggunaan limbah pertanian sebagai energi panas dalam pengeringan mempunyai kekurangan yakni dapat mencemari lingkungan. Bila kadar air limbah masih tinggi, maka ketika dibakar akan menciptakan asap di samping itu pengaturan suhu yang dikehendaki sulit dilakukan. Basmal (2013) menyebutkan bahwa untuk mendapatkan suhu yang dikehendaki selama proses pengeringan menggunakan tempurung kelapa perlu diatur jumlah tempurung kelapa yang akan dibakar secara periodik.

Liquified Petroleum Gas (LPG) merupakan bahan bakar hidrokarbon alami yang terbuat dari propan dan butan yang ramah lingkungan karena mengeluarkan karbon dioksida yang lebih rendah dari bahan bakar lainnya. Pengeringan menggunakan LPG juga memiliki kelebihan karena suhu dapat diatur sesuai dengan keinginan serta selama proses pengeringan tidak perlu dilakukan pengawasan secara terus menerus. Di samping itu 1 kg LPG dapat menghasilkan energi panas sebesar $11.200 \mathrm{kkal}$.

Tujuan dari ujicoba pengeringan ikan menggunakan pengering mekanis tipe vertikal dengan LPG sebagai sumber panas adalah untuk mengetahui kecepatan penurunan bobot ikan selama proses pengeringan serta mengetahui kinerja alat pengering.

\section{BAHAN DAN METODE}

\section{Bahan}

Jenis ikan yang digunakan dalam percobaan penentuan profil penurunan bobot selama proses pengeringan adalah ikan petek Leiognatus sp. yang diperoleh dari Tempat Pendaratan Ikan di Kabupaten Subang. Ikan sebelum dibawa ke Balai Besar Penelitian dan Pengembangan Pengolahan Produk dan Bioteknologi Kelautan dan Perikanan (BBP4B$\mathrm{KP}$ ) diberi perlakuan pengesan di dalam peti berinsulasi dengan rasio ikan : es curah $=1: 2$. Rata rata ukuran ikan yang digunakan dalam penelitian adalah panjang total 70-100 mm, lebar 30-45 mm dan tebal 10-15 mm. Sedangkan alat yang digunakan untuk pengeringan adalah alat pengering vertikal berdimensi panjang $600 \mathrm{~mm}$, lebar $600 \mathrm{~mm}$ dan tinggi $2.200 \mathrm{~mm}$. Alat pengering didisain menggunakan dinding akrilik dengan kapasitas $25 \mathrm{~kg} /$ batch proses. Sumber energi panas berasal dari LPG (Gambar 1).

\section{Metode}

Ikan petek sebelum dikeringkan terlebih dahulu direndam dalam larutan garam 3\% selama 1 jam. Hasil analisa kondisi awal kualitas ikan petek mempunyai kadar air sebesar 79,38\% dan kadar lemak 1,13\%. Jumlah ikan yang digunakan sebanyak $\pm 10,44 \mathrm{~kg}$ setiap ulangan dan dilakukan sebanyak tiga kali ulangan. Ikan disusun di atas 6 rak dengan kapasitas masing-masing rak 1,74 kg. Ikan petek yang sudah disusun di atas rak dan ditiriskan kemudian dimasukkan ke dalam ruang pengering secara bertingkat. Jarak antara rak yang satu dengan yang lainnya $10 \mathrm{~cm}$. Setelah ikan disusun di dalam ruang pengering kemudian energi panas dari LPG disalurkan ke dalam ruang pengering secara tidak langsung. Energi panas dari gas memanaskan pipa-pipa kemudian panas dari pipa disalurkan ke ruang pengering dengan cara ditarik menggunakan exhaust fan dengan kekuatan $50 \mathrm{~Hz}$ yang setara dengan 150 watt dengan kecepatan $2800 \mathrm{rpm}$. Diameter exhaust fan yang digunakan sebesar $20 \mathrm{~cm}$. Laju aliran LPG ke dalam alat pengering diatur sebesar $0,73 \mathrm{~g} /$ menit. 


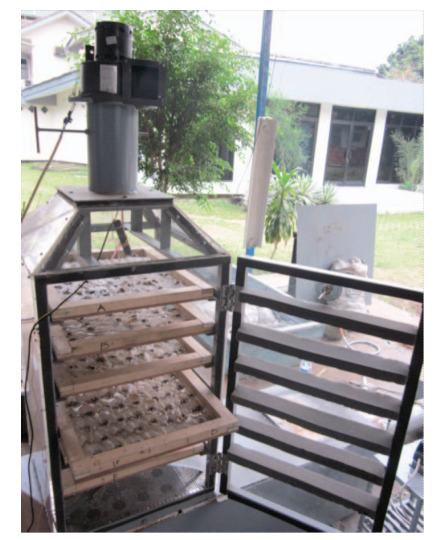

Keterangan/Note: Bagian cerobong asap dilengkapi dengan exhaust van, dinding terbuat dari akrilik, dan udara panas dilewatkan ke ruangan pengering dari bagian bawah/The chimney was equipped with exhaust fan. The surrounding wall was made from acrylic. Thermal air was passed from beneath part into the drying room.

Gambar 1. Alat pengering mekanis tipe vertikal.

Figure 1. Vertical type mechanical dryer.

Selama pengeringan, suhu, tingkat kelembaban dan penurunan bobot ikan dicatat.

Suhu diukur di bagian atas, tengah dan bawah dengan menggunakan termometer digital sedangkan tingkat kelembaban diukur pada bagian cerobong udara yang akan keluar dari ruang pengeringan menggunakan $\mathrm{Rh}$ meter. Untuk mengukur penurunan bobot ikan dilakukan penimbangan pada ikan yang sudah diberi tanda yang diletakkan di masing-masing rak selain itu dilakukan perhitungan kadar air (SNI

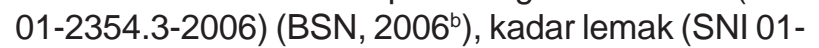
2354.2-2006)(BSN, 2006 ${ }^{a}$ ) dan nilai $a_{w}$ dengan alat Aw sprint model TH.

Jumlah kalori yang diperlukan untuk menarik air dari dalam daging ikan dihitung menggunakan persamaan $\mathrm{Q}=$ Berat ikan $(\mathrm{kg}) \times$ panas spesifik air $\left(\mathrm{KJ} / \mathrm{kg}^{\circ} \mathrm{C}\right) \times$ delta $\mathrm{T}\left({ }^{\circ} \mathrm{C}\right)$.

\section{HASIL DAN BAHASAN}

\section{Profil Suhu Pengeringan}

Hasil pengamatan menunjukkan fluktuasi suhu di dalam ruang pengering antara $26,04-55,86^{\circ} \mathrm{C}$ sedangkan suhu udara di sekitar alat pengering antara $26,95-35,95^{\circ} \mathrm{C}$. Data tersebut menunjukkan bahwa pembakaran LPG pada ruang pemanas dapat meningkatkan suhu di dalam ruang pengering. Pada Gambar 2 terlihat bahwa pada awal pengeringan suhu di dalam ruang pengering meningkat dengan tajam.

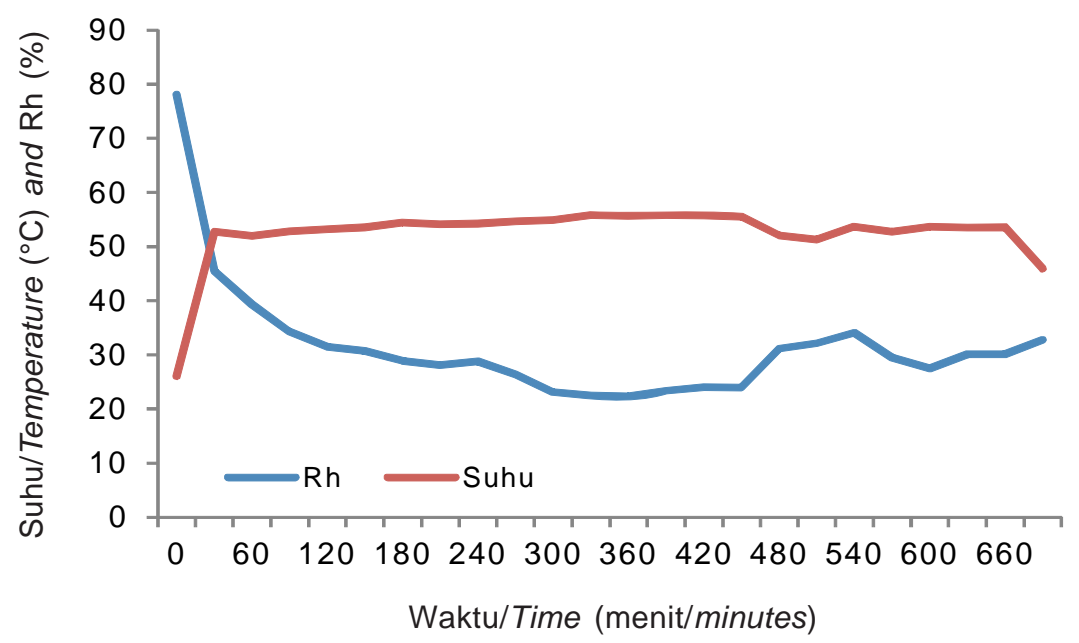

Gambar 2. Fluktuasi suhu dalam ruangan pengeringan dan kelembaban udara di sekitar alat pengering selama pengeringan.

Figure 2. Temperature and air moisture fluctuation in drying cabinet during of drying . 
Hal ini disebabkan adanya suplai energi panas dari pembakaran LPG. Sedangkan suhu udara di sekitar ruang pengering peningkatannya tidak terlalu tajam. Suhu di dalam ruang pengering dari menit ke 30 sampai dengan menit ke 450 relatif stabil dengan kisaran $52,73-55,52^{\circ} \mathrm{C}$ dengan rata rata suhu $52,40^{\circ} \mathrm{C}$, sedangkan suhu udara luar berkisar antara 26,95$35,95^{\circ} \mathrm{C}$, dengan rata rata $31,50^{\circ} \mathrm{C}$. Adanya perbedaan suhu sebanyak $20,91^{\circ} \mathrm{C}$ ini yang dapat menarik air dari dalam ikan. Jumlah kalori yang diperlukan untuk menarik sejumlah air dari dalam daging ikan sebanyak 913,84 KJ atau 218,413 kkal. Jika 1 kg LPG mempunyai energi panas sebesar $11.200 \mathrm{kkal} / \mathrm{kg}$ LPG, maka jumlah LPG yang digunakan selama proses pengeringan sebesar $3.465 \mathrm{~g}$ setara dengan $38.808 \mathrm{kkal} / 720$ menit proses pengeringan. Jumlah energi panas yang disalurkan dari LPG/menit sebesar $53,90 \mathrm{kkal} / \mathrm{menit}$, sedangkan jumlah energi panas yang diperlukan untuk menarik sejumlah air dari dalam ikan sebesar 7,28 kkal/menit, artinya tingkat efisiensi panas selama proses pengeringan sebesar 13,51\%.

Tingginya jumlah panas yang hilang disebabkan antara lain pada bagian cerobong telah dipasang exhaust fan/penarik udara dengan kekuatan daya hisap yang setara dengan $50 \mathrm{~Hz}$. Suhu ruang meningkat dengan cepat dari menit ke 0 sampai ke 30 yakni dari $26,03^{\circ} \mathrm{C}$ meningkat menjadi $52,73^{\circ} \mathrm{C}$ (Gambar 2). Terjadinya peningkatan suhu disebabkan oleh adanya suplai energi panas dari pembakaran LPG. Menurut Yaxiang Bai et al. (2011) dalam penelitiannya menggunakan elektrohidrodinamik/ electrohydrodynamic (EHD), peningkatan suhu di dalam ruangan pengering akan meningkatkan kecepatan penguapan air dari dalam produk yang dikeringkan. Air bebas, kecuali air terikat antar molekul dan air yang terikat dalam molekul daging ikan, mudah diuapkan. Untuk menguapkan air terikat antar molekul dan air yang ada dalam molekul daging ikan petek diperlukan energi panas yang lebih besar.

Hasil analisis kadar air ikan petek awal sebesar $79,38 \%$ dan setelah pengeringan selama 720 menit kadar air ikan petek berkurang menjadi 47,94\%. Adanya kandungan lemak dalam daging ikan petek juga dapat memperlambat penarikan air dari dalam daging ikan ke permukaan ikan. Hasil analisis lemak menunjukkan adanya peningkatan kadar lemak ikan petek setelah pengeringan dari $0,23 \%$ bk menjadi $0,59 \%$ bk. Peningkatan kadar lemak tersebut disebabkan oleh penurunan kadar air dari dalam ikan petek.

Peningkatan suhu di dalam ruang pengering mengakibatkan terjadinya penurunan bobot ikan. Berat awal ikan yang akan dikeringkan sebesar 10,44 kg dengan kadar air 79,38 atau setara dengan 8,29 kg air yang ada dalam ikan petek. Setelah proses pengeringan berat ikan petek menjadi $5,18 \mathrm{~kg}$ dengan kadar air 49,07\% atau setara dengan 2,54 kg air yang masih tertinggal di dalam daging ikan petek. Hasil perhitungan menunjukkan jumlah kandungan air yang dapat diuapkan selama 720 menit proses pengeringan sebesar 5,75 kg dengan rata-rata penguapan sebesar 7,98 g/menit. Pada Gambar 3 dapat dilihat penurunan bobot ikan selama proses pengeringan. Hasil perhitungan penurunan bobot ikan secara statistik mempunyai persamaan garis logaritma dengan rumus $y=-0,20 \ln (x)+1.006$ dengan nilai $r^{2}$ sebesar 0,999. Hal ini menunjukkan bahwa pemanfaatan bahan bakar LPG dalam proses pengeringan ikan petek

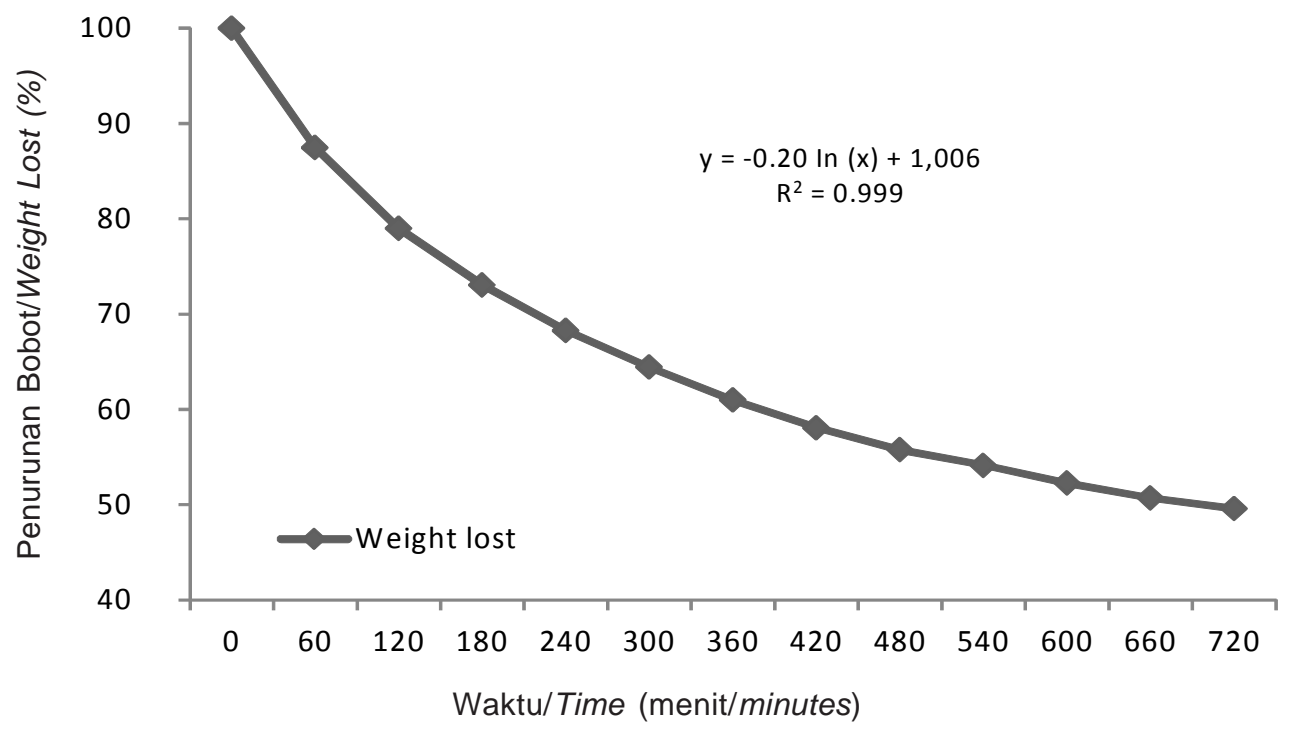

Gambar 3. Penurunan bobot ikan petek selama proses pengeringan.

Figure 3. Weight lost of Leiognathus sp. during drying process. 
menggunakan alat pengering mekanis tipe vertikal dapat menghasilkan penurunan bobot ikan secara teratur hingga mencapai titik yang konstan.

Kandungan air dari dalam daging ikan yang dapat diuapkan sangat erat hubungannya dengan perbedaan tingkat kelembaban udara di dalam dan di luar ruang pengeringan yang dihasilkan dari penggunaan bahan bakar LPG. Adanya selisih nilai kelembaban akan berdampak pada proses penguapan air dari dalam daging ikan petek. Hasil perhitungan statistik penurunan kandungan air ditemukan berbentuk persamaan garis logaritma $y=-12,5$ In $(x)+79,8$ dengan nilai $r^{2}=0,999$. Pada Gambar 4 terlihat pada menit ke 720 penurunan kadar air ikan sudah hampir mencapai titik keseimbangan, yang artinya laju kadar air akan mencapai titik keseimbangan. Hampir tercapainya titik keseimbangan kadar air tidak terlepas hubungannya dari sejumlah kalori yang diberikan oleh LPG yang diatur laju alirnya secara konstan sebesar 0,73 g/menit.

Pengaturan laju alir LPG ke dalam ruang pengering telah berdampak terhadap perbedaan tingkat kelembaban antara ruang pengering dan udara luar. Pada Gambar 5 dapat dilihat fluktuasi tingkat kelembaban antara udara luar dengan udara dalam ruang pengeringan.

Adanya perbedaan tingkat kelembaban udara dalam ruang pengeringan dan udara di luar ruang pengeringan disebabkan adanya suplai energi panas dari LPG sebesar 53,9 kkal/menit dan proses penarikan uap air dari permukaan ikan petek dibantu dengan exhaust fan yang dipasang pada cerobong.

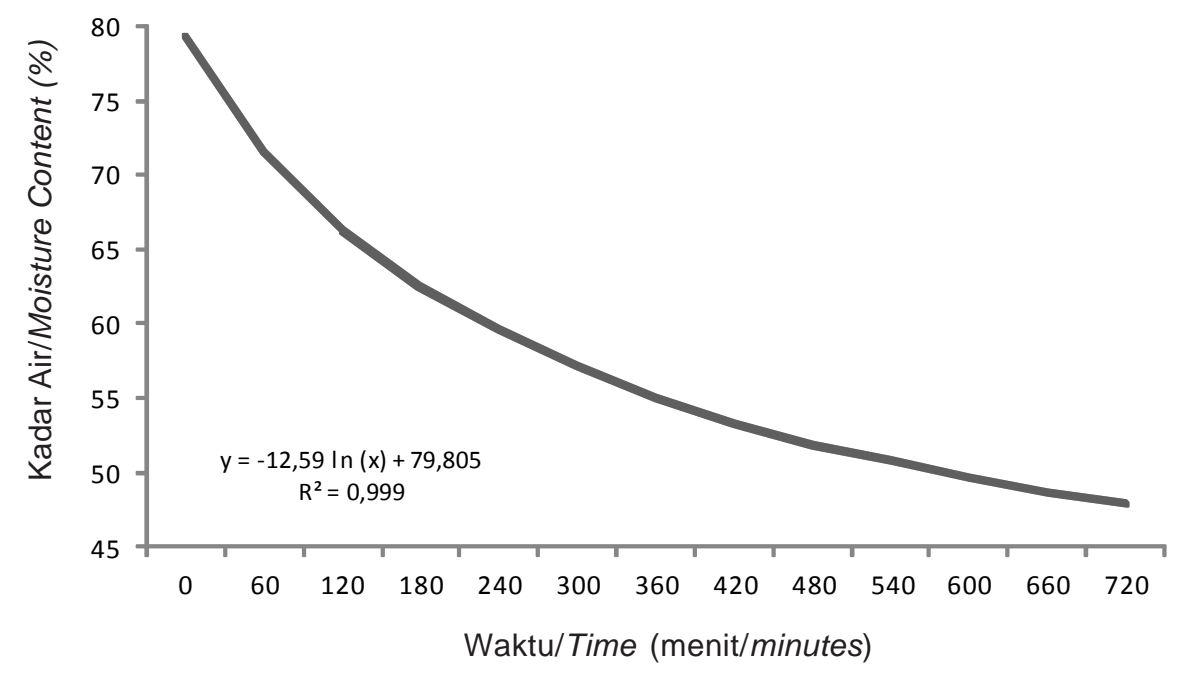

Gambar 4. Penurunan kadar air selama proses pengeringan. Figure 4. Reduction of moisture content during drying.

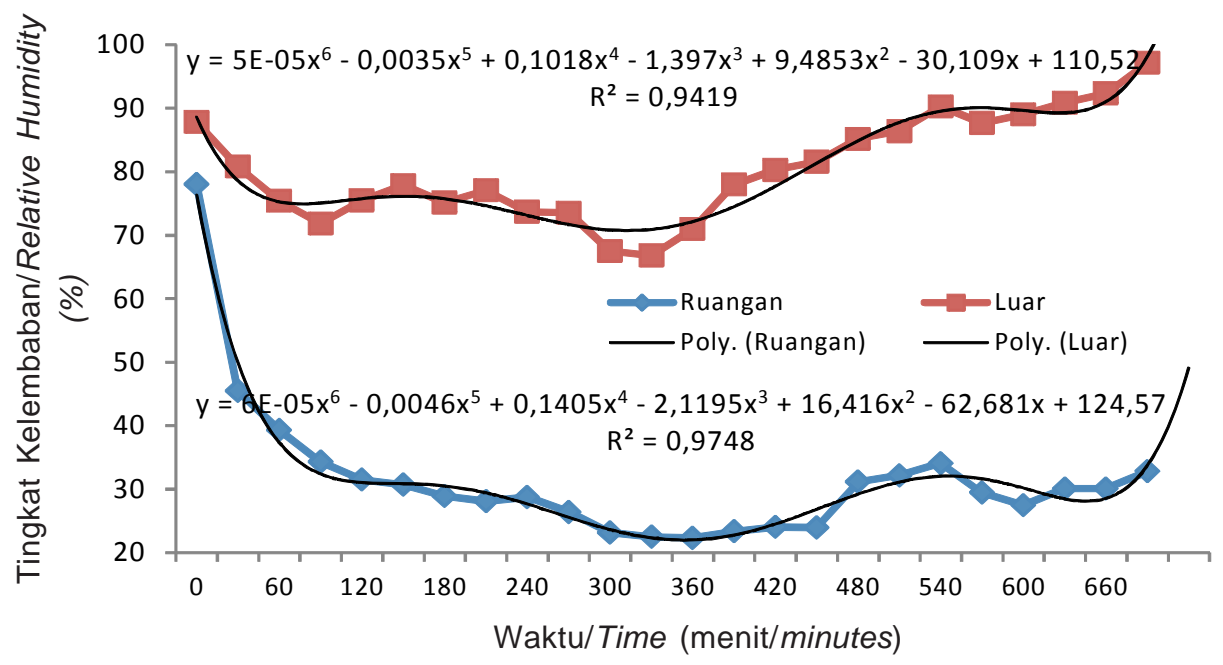

Gambar 5. Fluktuasi tingkat kelembaban udara di luar dan udara di dalam ruang pengeringan tipe vertikal. Figure 5. Fluctuation of relative humidity inside and outside drying chamber of vertical type dryer. 
Dengan kalori panas yang disuplai dari LPG sebesar $53,9 \mathrm{kkal} / \mathrm{menit}$, fluktuasi tingkat kelembaban di dalam ruang pengeringan menghasilkan persamaan garisnya berbentuk polinomial $y=6 E-0,5 x^{6}-0,004 x^{5}+0,140 x^{4}$ $-2,119 x^{3}+16,41 x^{2}-62,68 x+124,5$ dengan nilai $r^{2}=$ 0,974 . Sedangkan fluktuasi tingkat kelembaban udara di luar ruangan pengeringan ditemukan persamaan garis berbentuk polynomial $y=5 E-0,5 x^{6}-0,003 x^{5}$ $+0,10 x^{4}-1,397 x^{3}+9,485 x^{2}-30,10 x+110,5$ dengan nilai $r^{2}=0,941$. Fluktuasi tingkat kelembaban di dalam ruang pengeringan berkisar antara $22,3-78,05 \%$ dengan rata rata $32,74 \%$. Pada kisaran suhu antara $26,07-55,86^{\circ} \mathrm{C}$ dengan rata rata suhu $52,40^{\circ} \mathrm{C}$ dengan menggunakan rumus Raymond (1997): $\mathrm{Td}=(\mathrm{f} / 100)^{1 / 8}$ $x(112+0,9 T)+0,1 T-112$ ditemukan dew point $\left(T_{d}\right)$ sebesar $31,67^{\circ} \mathrm{C}$.

Tingkat kelembaban udara di luar ruang pengeringan antara 66,8-97,15\% dengan rata-rata $81,15 \%$. Pada kisaran suhu $26,95-35,95^{\circ} \mathrm{C}$ dengan rata rata suhu $31,50^{\circ} \mathrm{C}$ maka nilai dew point sebesar $27,86^{\circ} \mathrm{C}$. Artinya bahwa dengan adanya energi panas dari pembakaran LPG maka uap air dari dalam daging ikan petek akan terkondensasi di permukaan pada suhu dew point $\mathrm{T}_{d}=31,67^{\circ} \mathrm{C}$, sedangkan udara luar akan terkondensasi pada suhu dew point $T_{d}=27,86^{\circ} \mathrm{C}$. Menurut Yaxiang Bai et al. (2011) kecepatan pengeringan sangat dipengaruhi oleh perbedaan tingkat kelembaban antara ruang pengering dan udara luar, selanjutnya dikatakan semakin tinggi nilai tingkat kelembaban udara luar akan menurunkan kecepatan penarikan uap air dari dalam produk. Berdasarkan dew point udara luar $\left(T_{d}=27,86^{\circ} \mathrm{C}\right)$ seharusnya sudah terjadi kondensasi yang ditunjukkan dengan kecepatan penurunan bobot ikan yang melambat sehingga penurunan bobot ikan cenderung membentuk persamaan garis logaritma (Gambar 3). Penurunan bobot ikan dipengaruhi oleh penurunan kandungan air akibat adanya perbedaan tingkat kelembaban antara udara sekitar ikan dan di dalam daging ikan petek.

Hasil perhitungan dew point di dalam ruang pengeringan sebesar $\mathrm{T}_{d}=31,67^{\circ} \mathrm{C}$, artinya uap air yang berasal dari dalam daging ikan akan mengembun di dalam ruang pengeringan pada suhu tersebut, tetapi dengan adanya exhaust fan yang dipasang di cerobong ruang pengering titik-titik air di permukaan ikan akan langsung dihisap oleh exhaust fan. Menurut Mathlouthi (2001) nilai dew point biasa digunakan dalam menentukan nilai $a_{w}$ permukaan produk yang dikeringkan. Selanjutnya dikatakan suhu yang berembus dipermukaan produk yang dikeringkan akan menyebabkan air dari dalam daging ikan terdifusi ke permukaan sebagai akibatnya akan terjadi kejenuhan air dan mulai terkondensasi akibat pendinginan udara dan akan mempengaruhi tekanan uap sebagai konsekuensinya mempengaruhi nilai $a_{w}$ permukaan produk yang dikeringkan.

Fluktuasi tingkat kelembaban akibat pemberian kalori panas dari LPG akan berpengaruh pula terhadap kadar air ikan petek selama pengeringan. Hal ini disebabkan semakin rendah tingkat kelembaban udara di sekeliling ikan petek yang dikeringkan akan semakin tinggi tingkat penarikan air yang terkondensasi dipermukaan ikan petek. Pada Gambar 6 dapat dilihat hubungan tingkat kelembaban udara di dalam ruang pengering dengan kadar air ikan petek selama proses pengeringan.

Kecepatan proses pengeringan ikan akan sangat ditentukan oleh dua faktor yakni faktor internal yang menyangkut kondisi ikan seperti tingkat kesegaran ikan, ukuran dan komposisi kandungan (lemak,

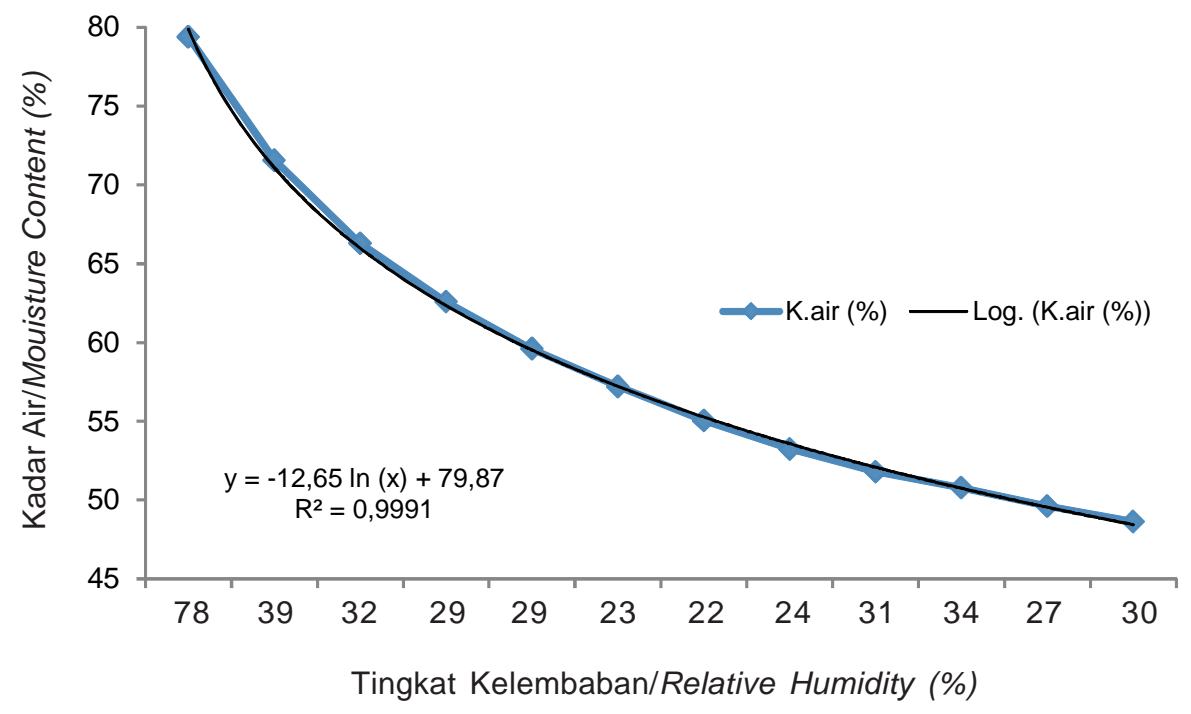

Gambar 6. Hubungan kadar air dengan tingkat kelembaban.

Figure 6. Relationship between moisture content and relative humidity. 
protein, mineral dan air) ikan serta faktor eksternal seperti perubahan suhu dan tingkat kelembaban, kecepatan aliran udara di sekitar ikan yang dikeringkan dan tipe alat pengering yang digunakan. Menurut Chipman \& Langstroth (1929) panas spesifik ikan pada suhu $0-60^{\circ} \mathrm{C}$ sekitar $0,89 \mathrm{kkal} / \mathrm{kg}^{\circ} \mathrm{C}$. Berdasarkan teori Chipman \& Langstroth (1929) diperoleh jumlah kalori yang dibutuhkan untuk meningkatkan suhu dari suhu awal 26,56 menuju $55,76^{\circ} \mathrm{C}$ sebanyak $276,52 \mathrm{kkal}$ yang harus dipertahankan selama 720 menit proses pengeringan. Jumlah energi panas yang diperlukan untuk mempertahankan kebutuhan energi tersebut yang diperoleh dari pembakaran LPG adalah sebesar $38.808 \mathrm{kkal}$. Adanya potensi kehilangan energi panas selama proses pengeringan telah disebabkan oleh adanya udara panas yang ditarik keluar dari ruang pengering, rambatan panas ke dinding pengeringan dan panas yang digunakan untuk menaikan suhu serta menurunkan tingkat kelembaban udara yang masuk ke dalam ruang pengeringan. Oleh sebab itu potensi energi panas yang hilang akibat faktor eksternal sebesar 38.531,48 kkal.

Abbas et al. (2009) menyatakan nilai $a_{w}$ berhubungan dengan kadar air dalam bentuk persamaan non linear sorption isotherm. Hasil penelitian menunjukkan bahwa antara kadar air dengan nilai $a_{w}$ membentuk persamaan logaritma y $=-12,6 \ln (x)+79,87$ dengan nilai $r^{2}=0,999$, artinya penurunan kadar air akan diikuti pula dengan penurunan nilai $a_{w}$. Nilai $a_{w}$ sebelum pengeringan 0,753 dan setelah pengeringan mencapai 0,483 atau telah terjadi penurunan nilai $a_{w}$ sebesar $35,86 \%$.

Berdasarkan Gambar 7, nilai $a_{w}$ dan kandungan air di dalam daging ikan akan mempengaruhi kualitas ikan selama proses penyimpanan. Reaksi penurunan mutu ikan sebelum dikeringkan lebih dominan disebabkan oleh oksidasi lemak dan proses pencoklatan sedangkan penurunan mutu akibat aktivitas bakteri lebih lambat. Hal ini mungkin disebabkan ikan sebelum dikeringkan telah digarami terlebih dahulu sehingga hanya bakteri yang tahan garam yang mungkin masih dapat bertahan untuk hidup. Setelah pengeringan reaksi yang masih mungkin terjadi adalah reaksi enzimatik, reaksi hidrolitik, proses oksidasi dan pencoklatan akibat reaksi lemak masih terjadi tetapi relatif lebih kecil dibandingkan sebelum ikan dikeringkan.

Berdasarkan Gambar 7 ternyata penggunaan LPG dalam ujicoba pengeringan ikan petek menggunakan alat pengering tipe vertikal mampu menurunkan kadar air dan nilai $a_{w}$. Hal ini menunjukkan adanya kemampuan untuk menekan pertumbuhan bakteri khususnya $S$. aureus dan $B$. cereus yang mungkin berasal dari kontaminasi silang antara pekerja dan ikan selama pengeringan. Telah diketahui bahwa S. aureus merupakan mikroflora normal manusia

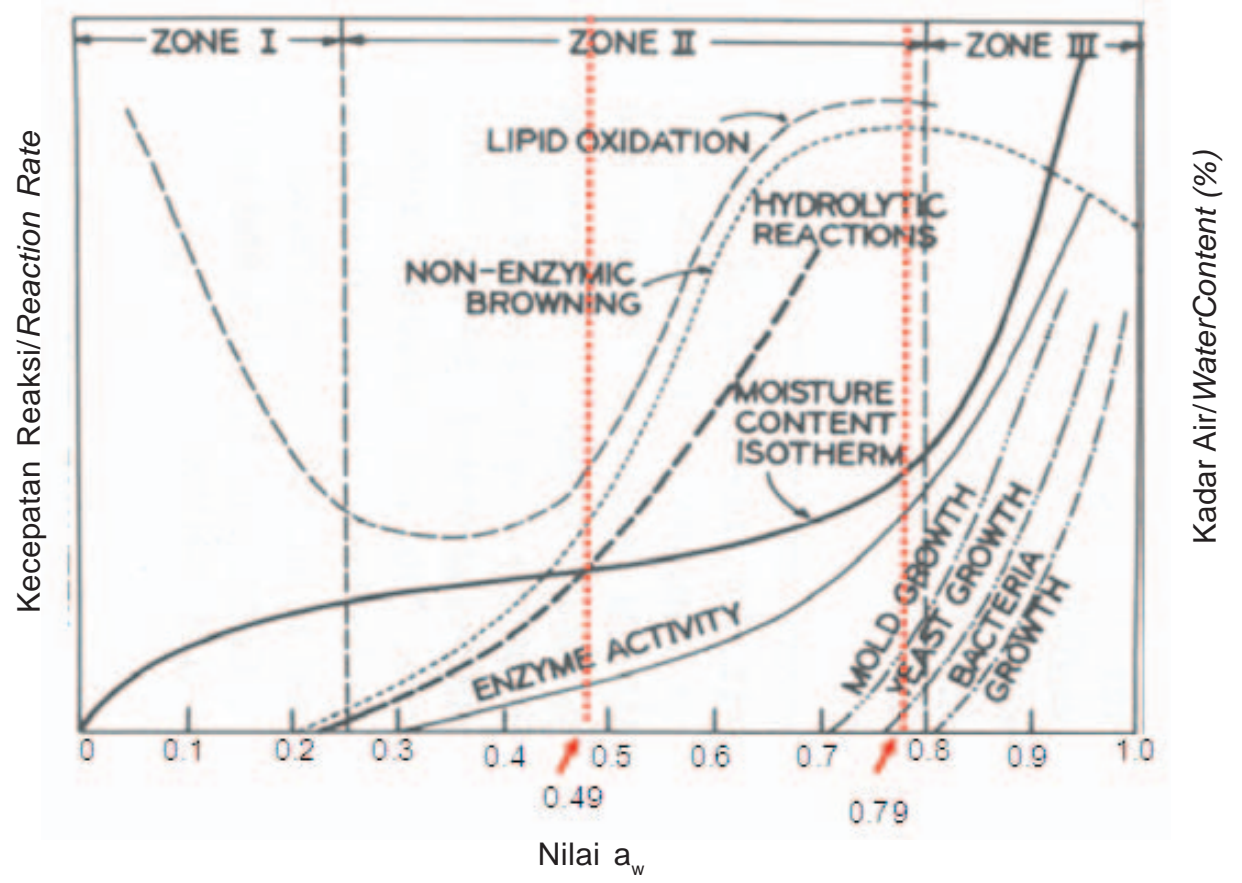

Sumber: Abbas et al. (2009)

Gambar 7. Hubungan antara nilai $a_{w}$, kadar air dan kecepatan reaksi penurunan mutu ikan.

Figure 7. Relationship between $a_{w}$ value, water content and rate of fish quality deterioration. 


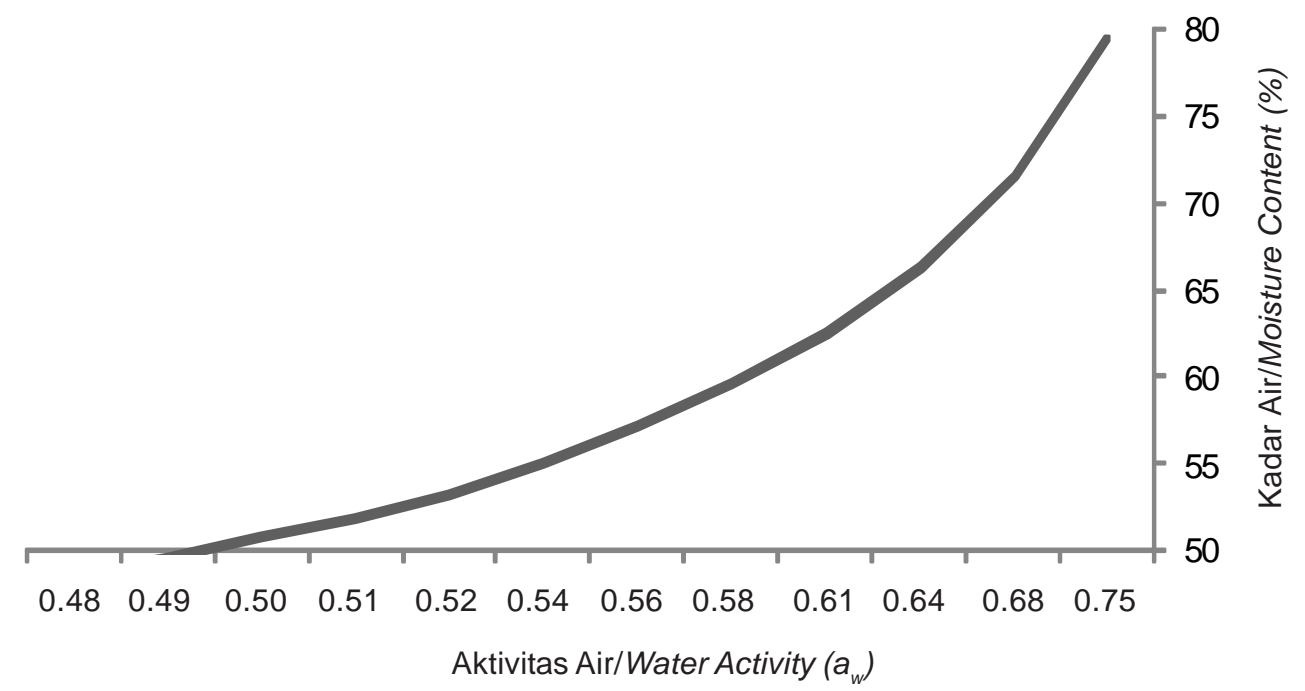

Gambar 8. Hubungan kadar air dengan nilai $a_{w}$ ikan petek selama pengeringan.

Figure 8. Relationship between moisture content and water activity of Leiognathus sp. during drying.

(Prescott et al., 2002). Selanjutnya (Honeyman et al., 2001 dan Madigan et al., 2008) melaporkan bahwa bakteri ini biasanya terdapat pada saluran pernapasan atas dan kulit. Keberadaan S. aureus pada saluran pernapasan atas dan kulit pada individu jarang menyebabkan penyakit, individu sehat biasanya hanya berperan sebagai pembawa. Sedangkan $B$. cereus merupakan jenis bakteri yang perlu mendapat perhatian terutama pada produk yang dipanaskan pada suhu di bawah atau sama dengan $100^{\circ} \mathrm{C}$ dalam waktu yang lama. Hal ini dapat memungkinkan beberapa spora $B$. cereus untuk bertahan hidup dan berkembang (Robert et al., 1996; Turnbull, 1996; McKillip, 2000). Gejala yang timbul bila mengkonsumsi makanan yang terkontaminasi dengan $B$. cereus ini adalah mual, muntah, dan diare (Kotiranta et al., 2000 dan EhlingSchulz et al., 2004).

Menurut Medveïová et al. (2009) pertumbuhan mikroorganisme dalam produk sangat tergantung pada ketersediaan kandungan air dan nilai $a_{w}$ produk. Selanjutnya dikatakan oleh Troller \& Stinson (1975); Sutherland et al. (1994) dan Baird-Parker (2000) dalam Medveïová et al. (2009) bahwa pertumbuhan mikroorganisme $S$. aureus dalam kaitannya dengan nilai $a_{w}$ akan tumbuh pada kisaran nilai $a_{w} 0,83-0,86$, tetapi pertumbuhannya juga akan tergantung pula oleh nilai $\mathrm{pH}$, suhu, humectants, dan kondisi lingkungan seperti suhu dan tingkat kelembaban udara. Hagen et al. (1967); Quintavalla \& Parolari (1993) dalam Staack et al. (2008) menyatakan $B$. cereus dengan nilai $a_{w}$ di bawah 0,8 akan terhambat pertumbuhannya dan bahkan cenderung untuk tidak aktif/dorman. Berdasarkan pernyataan di atas berarti penggunaan LPG untuk menghasilkan energi panas dalam proses pengeringan menggunakan alat pengering tipe vertikal berpotensi untuk menghambat pertumbuhan mikroorganisme $S$. aureus dan $B$. cereus selama proses pengeringan. Pada Gambar 8 dapat dilihat kurva penurunan nilai $a_{w}$ dalam kaitannya dengan penurunan kadar air selama proses pengeringan ikan petek menggunakan alat pengering tipe vertikal.

\section{KESIMPULAN}

Alat pengeringan tipe vertikal dapat menurunkan bobot ikan sebesar $52 \%$ dan nilai $a_{w}$ dari 0,79 menjadi 0,48 . Selama proses pengeringan, rata-rata suhu pemanasan, tingkat kelembaban dan dew point adalah sebesar $52,4^{\circ} \mathrm{C}, 52,4 \%$, dan $30,08^{\circ} \mathrm{C}$.

\section{DAFTAR PUSTAKA}

Abbas. K.A.,Saleh, A.M., Mohamed, A., and Ola Lasekan. 2009. The relationship between water activity and fish spoilage during cold storage: A review. Journal of Food, Agriculture \& Environment. 7(3 \& 4): 86-90.

Bala, B.K. 1997. Drying and Storage of Cereal Grains. Oxford \& IBH Publishing Co. Pvt.Ltd. India.

Bala, B.K. and Mondal, M.R.A. 2001. Experimental investigation of solar drying of fish using solar tunnel dryer. Dry Technol. 19(2): 1-10.

Bala, B.K, Mondol, M.R.A, Biswas, B.K, Das Choudhury, B.L., and Janjai, S. 2003. Solar drying of pineapple using solar tunnel drier. Renew Energy 28: 183-190.

Basmal, J., Erawan, I.M.S., dan Arifin, Z. 2013. Uji performansi alat pengering mekanik tipe vertikal menggunakan tempurung kelapa sebagai sumber panas. Jurnal Pascapanen dan Bioteknologi-KP (inprogress)

Badan Standardisasi Nasional (BSN). 2006ª . Cara Uji Kimia Bagian 2: Penentuan Kadar Air pada Produk 
Perikanan. Badan Standardisasi Nasional. SNI 012354.2-2006. ICS-67.120.30.

Badan standardisasi Nasional (BSN). 2006 ${ }^{\mathrm{b}}$. Cara Uji Kimia Bagian 3: Penentuan Kadar Lemak pada Produk Perikanan. Badan satndardisasi Nasional. SNI 01-2354.3-2006.ICS-67.120.30.

Chipman. H.R. dan Langstroth, G.O. 1929. Some mesurement of the head capacity of fish muscle. Hand Book Capacity of Fish Muscle. pp. 175-183.

Ehling-Schulz, M., Fricker M., and Scherer, S. 2004. Bacillus cereus, the causative agent of an emetic type of food-borne illness. Mol. Nutr. Food Res. 48(7): 47987.doi:10.1002/mnfr.200400055. PMID 15538709.

Exell, R.H.B., and Kornsakoo, S. 1978. A low-cost solar rice dryer. Appropriate Technol 5: 23-24.

Exell, R.H.B., and Kornsakoo, S. 1980. Basic design theory for a simple solar rice dryer. Renew Energy. Review J. 1: 1-14.

Esper, A. and Muhlbaure, W. 1993. Development and Dissemination of Solar Tunnel Drier. ISES Sol World Cong, Budapest 22.

Esper, A. and Mühlbauer, W. PV. 1994. Driven Solar tunnel drier. Agri Eng Conf, Bangkok, December 6-9.

Honeyman, A.L., Friedman, H., and Bendinelli, M. 2001. Staphylococcus aureus Infection and Disease. New York: Plenum Publishers.

Horwizt. 1980. Official Methods of Analysis on the Association of Official Analytic Chemist. Horwitzs, 1981. (ed.). Washington D.C. p. 550.

Hossain, MA. 2003. Forced Convection Solar Drying of Chilli. PhD thesis. Bangladesh gricultural University. Mymensingh.

Hossain, M.A., Bala, B.K., and Woods, J.L. $2005^{a}$. Simulation of solar drying of chilli in solar tunnel drier. Int Journal Sustainable Energy. 24: 143-153.

Hossain, M.A., Woods, J.L., and Bala, BK. $2005^{\mathrm{b}}$. Optimization of solar tunnel drier for drying of chilli without color loss. Renew Energy. 30: 729-742.

Hossain, MA, and Bala, BK. 2007. Drying of hot chilli using solar tunnel drier. Journal Sol Energy. 81: 8592.

Karim, M.A. and Hawlader, M.N.A. 2005. Mathematical modeling and experimental investigation of tropical fruits drying. Int. J. Heat Mass Trans. 48: 4914-4925.

Kotiranta, A., Lounatmaa, K., and Haapasalo, M. 2000. Epidemiology and pathogenesis of Bacillus cereus infections. Microbes Infect. 2(2): 189-98. doi:10.1016/ S1286-4579(00)00269-0. PMID 10742691.

Madigan, M.T., Martinko, J.M., Dunlap, P.V., and Clark, D.P. 2008. Biology of Microorganisms 12th edition. San Francisco
Mathlouthi, M. 2001. Water content, water activity, water structur and the stability of foodstuffs. Journal Food Control. 12: 409-417.

McKillip, J.L. 2000. Prevalence and Expression of Enterotoxins in Bacillus cereus and other Bacillus spp., A Literature Review. Antonie Van Leeuwenhoek 77(4): 393-9. doi:10.1023/A:1002706906154. PMID 10959569.

Medveïová. A., 1/4ubomír Valík, and Adriana Studenièová. 2009. The Effect of Temperature and Water Activity on the Growth of Staphylococcus aureus. Czech J. Food Sci. Vol. 27, 2009, Special Issue. 2: 28-35.

Muhlbauer, W. 1986. Present status of solar crop drying. Energy in Agri. 5: 121-37.

Ratti. C. and Majumdar, A.S. 1997. Solar drying of foods: modeling and numerical simulation. Sol Energy. 60: 151-157.

Raymond. J. 2012. Dew point Equation Formulas Calculator. Meteorology Weather Water vapor. Reference books: Wanielista. M., R. Kersten and Ron Eaglin. 1997. Hydrology Water Quality and Quality Control. John Wiley \& Sons. $2^{\text {nd }}$ ed.

Roberts, T. A., Baird-Parker, A.C., and Tompkin, R.B. 1996. Characteristics of Microbial Pathogens. Books: Microorganisms in Foods 5: London: Blackie Academic \& Professional. p. 24. ISBN 0-412-47350X. Retrieved 25 November 2010. Kluwer Academic/ Plenum Publisher.

Oosthuizen, P.H. 1995. The design of indirect solar rice dryers. J Eng International Development. 2: 20-27.

Oosthuizen, PH. 1996. Experimental study of simulated indirect solar rice dryer fitted with a small fan. J. Eng. International Development. 3: 22-29.

Prescott, L.M., Harley, J.P., and Klein, D.A. 2002. Microbiology. 5th Ed. Boston: McGraw-Hill.

Sharma, V.K., Colalgelo, A., and Spagna, G. Ex 1995. perimental investigation of different solar dryers suitable for fruits and vegetables drying. Renew Energy. 6(4): 413-424.

Staack, N., Ahrné, L., Borch, E., and Knorr, D. 2008. Effects of temperature, $\mathrm{pH}$, and controlled water activity on inactivation of spores of Bacillus cereus in paprika powder by near-IR radiation. Journal of Food Engineering. 89: 319-324.

Turnbull P.C.B. 1996. Bacillus. (Chapter 15). In Baron's (ed.). Medical Microbiology. Galveston, Texas. http:// www.ncbi.nlm.nih.gov/books/NBK7699/\#939

Yaxiang Bai, Xinjun LI, Yang Sun and Hu Shi. 2011. Thin layer electrohydrodynamic (EHD) drying and mathematical modeling of fish. International Journal of Applied Electromagnetics and Mechanics 36 (2011) 217-228 217. DOI 10.3233/JAE-2011-1361.

Zaman, M.A, and Bala, B.K. 1989. Thin layer solar drying of rough rice. Sol Energy. 42: 167-171. 
